\title{
INTRODUCTION
}

\section{Tagging through the stages: technical and ecological challenges in observing life histories through biologging}

\author{
George L. Shillinger ${ }^{1,2, *}$, Helen Bailey ${ }^{3}$, Steven J. Bograd ${ }^{4}$, Elliott L. Hazen ${ }^{4}$, \\ Mark Hamann ${ }^{5}$, Philippe Gaspar ${ }^{6}$, Brendan J. Godley ${ }^{7}$, Rory P. Wilson ${ }^{8}$, \\ James R. Spotila ${ }^{9}$ \\ ${ }^{1}$ Center for Ocean Solutions, Stanford University, 99 Pacific Street, Suite 155A, Monterey, California 93940, USA \\ ${ }^{2}$ Tag-A-Giant Fund - The Ocean Foundation, PO Box 52074, Pacific Grove, California 93950, USA \\ ${ }^{3}$ Chesapeake Biological Laboratory, University of Maryland Center of Environmental Studies, Solomons Island, \\ Maryland 20688, USA \\ ${ }^{4}$ NOAA Southwest Fisheries Science Center, Environmental Research Division, 1352 Lighthouse Avenue, Pacific Grove, \\ California 93950, USA \\ ${ }^{5}$ School of Earth and Environmental Sciences, James Cook University, Townsville, Queensland 4811, Australia \\ ${ }^{6}$ Collecte Localisation Satellites, Satellite Oceanography Division, Department of Marine Ecosystems, 8-10 rue Hermès, \\ 31520 Ramonville St Agne, France \\ ${ }^{7}$ Centre for Ecology and Conservation, School of Biosciences, University of Exeter, Cornwall Campus, Penryn TR10 9EZ, UK \\ ${ }^{8}$ School of Biological Sciences, University of Wales Swansea, Singleton Park, Swansea SA2 8PP, UK \\ ${ }^{9}$ Department of Biology, Drexel University, Philadelphia, Pennsylvania 19104, USA
}

\begin{abstract}
Biologging data have provided important insights into the biology of marine mammals, sea turtles, birds, fish, and some invertebrates. These techniques have primarily targeted adult organisms. As a result, the early life histories of many marine species are still poorly understood. Technological advances have enabled attachment of smaller tags to young animals, although equipment limitations, access to and capture/handling of animals, and equipment and data recovery pose additional challenges to researchers. In this Theme Section, we highlight novel uses of biologging data on juvenile animals, including reviews of tagging efforts on multiple lifehistory stages and the integration of oceanographic data in tagging efforts.
\end{abstract}

KEY WORDS: Electronic tags · Tag attachment techniques · GPS tags · Juveniles · Ocean currents · Ontogeny $\cdot$ Hatchling dispersal models $\cdot$ Satellite telemetry $\cdot$ Conservation

Broad-scale anthropogenic impacts, such as climate change, affect all life stages of a species (Brander 2010, Costa et al. 2010, Evans et al. 2010, Fuentes et al. 2011). Advances in understanding the physiology, behavior, and ecology of many marine species have been made through the use of biologging techniques (Mate et al. 2007, Wilson et al. 2008, RopertCoudert et al. 2009, Block et al. 2011), which involve attaching electronic tags to animals (Hooker et al.
2007, Rutz \& Hays 2009). These techniques have primarily targeted adult organisms, which tend to have higher survival rates than younger life stages. In addition, larger tags can hold more sensors, greater data storage, and larger batteries, resulting in longer deployments (McConnell et al. 2010). Biologging data have provided important insights into the biology of marine mammals, sea turtles, birds, fish, and some invertebrates (Godley et al. 2008, Hays et al. 
2008, Rutz \& Hays 2009, Bograd et al. 2010). However, there are few tagging studies on young life stages, and the early life histories of many marine species are still poorly understood (Hazen et al. 2012).

Improvements in biologging technology have resulted in substantial tag miniaturization and enhanced data compression (Fedak et al. 2002). Although it is now possible to attach small tags to young animals (Mansfield et al. 2012), the small size of these tags limits the number of sensors and length of battery life. Thus, it is essential that careful thought goes into what research questions need to be answered and what types of, and how much, data need to be collected to answer these questions (Breed et al. 2011). Attachment mechanisms, durations, and data needs vary greatly across taxa. Young life stages tend to grow rapidly, often requiring attachment methods that are flexible enough to accommodate growth. Assessment in the field or laboratory of suitable attachment methods is necessary to ensure that any tagging effort has minimal impact on the animals and that the benefits of tagging are not outweighed by the costs (Wilson \& McMahon 2006, Mansfield et al. 2012).

High mortality during early life history stages makes it difficult to recover tags, may shorten the period of data collection, and may compromise the data set when predation occurs (Hays et al. 2007, Baker 2008, Snoddy \& Southwood Williard 2010). Deploying a large number of tags may therefore be necessary to ensure sufficient sample size, particularly if population processes are of interest (Lindberg \& Walker 2007). Sample sizes in biologging are generally limited by available funds, so this may require the use of simpler, more inexpensive tags, and careful selection of the type of sensors they contain.

The Editors of this Theme Section convened a workshop entitled 'Tagging through the Stages: Technical and Ecological Challenges in Observing Life Histories through Biologging' on 16 March 2011 in association with the Biologging IV Symposium in Hobart, Tasmania, Australia, with these technical and ecological challenges in mind. Over 40 scientists and tag manufacturers from Australia, North America, Europe, and Japan attended the workshop. The objectives were to (1) establish the current state of knowledge and technologies for studying young life stages, (2) stimulate interdisciplinary discussion regarding ontogeny and biologging, (3) review and discuss tag design and attachment techniques, and (4) integrate a life history perspective within the field of biologging. There were 18 presentations organized in 3 categories: (1) Tag Techniques and Devel- opment, (2) Applications, and (3) Models. The studies within this Theme Section represent a selection from the workshop and feature recent advances in our understanding of the life history of marine species and in particular young life stages.

\section{Tag techniques and development}

Advances in tagging technology, such as tag miniaturization, increased data storage and transmission capabilities, and improved analytical methodologies, are providing researchers with important tools for understanding the biology of marine species and their environment (Fedak et al. 2002). The development of fast-acquisition GPS tags, such as Fastloc GPS, has provided increasingly accurate location estimates for species that spend little time at the surface. Shimada et al. (2012) propose a new filtering method for these data that will reduce the linear error of Fastloc GPS locations to $47 \mathrm{~m}$ while retaining more than $94 \%$ of the data. This increases the accuracy of home range estimates.

Ethical issues of whether the benefits of the scientific research outweigh the costs of disturbance and possible harm to the animals are a key concern when catching and tagging juvenile animals (Godley et al. 2008). In some cases, young animals may be too small or delicate to carry tags and less invasive research techniques are more appropriate. Assessment of the best techniques and practices will help to ensure that any impacts to the animals are kept to a minimum. Mansfield et al. (2012) describe the first satellite tracks of any neonate sea turtle and the first in situ data of the movements of neonate loggerheads Caretta caretta. They tested several methods for attaching small solar-powered satellite tags, first in the laboratory to determine whether there were any apparent effects on growth or body condition, and then in the field to establish retention durations and to assess the performance of antifoulants (Mansfield et al. 2012). There is increasing evidence that general guidelines and practices may not well reflect speciesspecific and longer-term harmful tag effects (SherrillMix \& James 2008, Vandenabeele et al. 2012).

Assessing effects of drag may also be possible using computer simulations, to determine how an animal's physiology or morphology may assist with creating hydrodynamic tag designs and attachment techniques (Pavlov \& Rashed 2012). Abnormal swimming behavior and increased energetic demands can occur if the tag causes high drag (Hammerschlag et al. 2011, Jones et al. 2011). Designing tags and 
attachments that will reduce drag is therefore of key importance for marine species that rely on swimming to capture prey or escape predators, and during flight for seabirds (Phillips et al. 2003, Wilson \& McMahon 2006, Heithaus et al. 2007, Vandenabeele et al. 2012).

Accommodating the rapid rate of growth in young life stages remains a challenge for tag attachment techniques. Implantable tags may be necessary for studying animals over longer time periods and across life history stages (Horning \& Hill 2005). Implantable tags have been effectively used in fish (Block et al. 2005). For example, data on depth and temperature have been used to study changes during different stages of the breeding migration in bluefin tuna Thunnus thynnus (Teo et al. 2007).

\section{Applications}

Biologging has contributed significant insights that inform conservation management and population recovery efforts by identifying important habitats, risks and impacts, and helping to plan effective mitigation measures (Mate et al. 2007, Shillinger et al. 2008, McClellan et al. 2009). This has included the ability to identify life history changes and potential harvest events. Hart et al. (2012) describe the habitat use of juvenile hawksbill turtles Eretmochelys imbricata that had core-use areas within a national park. Two of the tagged turtles migrated from the exclusive economic zone of the USA into Cuban waters, where they may have been harvested.

Neonate, juvenile, and subadult animals tend to behave and move differently than do adults, which may be a result of reduced diving and swimming capabilities early in life, and/or may reduce competition for resources (Campagna et al. 2007). Protection by the mother can make it difficult to tag some young animals, and their unpredictable movements can limit tag recovery and thus bias estimates of survival (Bradshaw et al. 2000). Tyson et al. (2012) attached high-resolution digital acoustic recording tags (Dtags) to a mother and calf humpback whale Megaptera novaeangliae pair in Wilhelmina Bay (Western Antarctic Peninsula) to examine their concurrent diving and foraging behavior. The pair appeared to dive in synchrony for much of the tag duration while maintaining close proximity (Tyson et al. 2012). These results validate findings that humpback whale calves accompany their mothers following parturition, remaining within several body lengths until they separate permanently (Szabo \& Duffus 2008).
Although the number of biologging studies on immature animals has been small relative to studies on adults (Hazen et al. 2012), an increasing number of recent studies, such as those on loggerhead turtles (Mansfield et al. 2009, 2012, Seney et al. 2010), green turtles Chelonia mydas (Hart \& Fujisaki 2010), and flatback turtles Natator depressus (Salmon et al. 2009), have coupled advances in tag miniaturization with innovative deployment techniques to obtain critical information about the dispersal and movements of juvenile animals. Data regarding this early life history phase are essential because it represents a large proportion of the life span for many long-lived species. Moreover, experiences during these periods are often diverse as these animals undergo transition between nursery, foraging, and breeding habitats, which can exert a strong influence upon the population status.

Barbour \& Adams (2012) used passive integrated transponders and found that common snook Centropomus undecimalis had high site fidelity within specific life history stages, but changed habitat as they transitioned from juvenile to adult. In another example, Melnychuk et al. (2012) utilized acoustic tagging methods to examine the hypothesis that exposure of coho Oncorhynchus kisutch and sockeye salmon $O$. nerka to solar UV-B radiation during freshwater rearing of fry and parr increases mortality at the time of smoltification and ocean entry. They found that while exposure to UV-B resulted in stunted growth of juvenile coho salmon, survivorship during the early marine period was unaffected by the UV-B treatment for both populations. These results challenge one of the many hypotheses for declines in marine survival rates of salmon populations.

\section{Models}

There are cases, such as for very young animals, where biologging may not currently be the most appropriate technique or the study design could be improved by first gaining some basic knowledge about when and where the animals are going and how they are dispersing. Ocean models provide a valuable resource for investigating potential dispersal patterns and have been of particular use in studying sea turtles (Hays \& Marsh 1997, Hamann et al. 2011, Scott et al. 2011). Very little is known about the movements of hatchling turtles after they leave the beach, until they return as adults decades later. As adults, sea turtles show fidelity to their natal nesting areas and then at the end of the breeding season may migrate to distant foraging sites. Hays et al. (2010) 
hypothesized a hatchling drift scenario whereby the foraging sites used by individual sea turtles reflect their previous experiences as young juveniles, when they were carried by ocean currents. The pattern of adult dispersion from the breeding area for loggerhead turtles in the Mediterranean reflects the extent of passive drift experienced by hatchlings (Hays et al. 2010). Simulations of leatherback hatchling dispersal in the western Pacific by Gaspar et al. (2012) similarly found that adults targeted favorable foraging areas inside the juveniles' drift area. However, there were drift areas where no adults have been observed (Gaspar et al. 2012). This could occur as a result of high juvenile mortality along drift trajectories towards such areas, or because of a low return rate if the return route to the natal area is difficult to traverse or navigate. Shillinger et al. (2012) investigated leatherback turtle hatchling dispersal in the eastern Pacific Ocean using passive tracer experiments within a Regional Ocean Modeling System. Tracer distribution suggested that hatchling leatherbacks entering the ocean in late winter are rapidly and efficiently transported offshore within eddies, which may provide a productive refuge for them.

These simulations of hatchling dispersal based on ocean models can further be refined through laboratory and field-derived estimates of their swimming behavior (Wyneken et al. 2008, Okuyama et al. 2009, Salmon et al. 2009). Ocean currents may be critical for determining the dispersal of hatchlings and subsequent migrations as adults. Fossette et al. (2012) reviewed various techniques for estimating current velocities, or more directly, passive drift trajectories. All methods have errors that need to be taken into account when inferring about animal behavior, and in particular, swimming activity (e.g. Jonsen et al. 2005).

\section{Conclusions}

There are several challenges in biologging-related conservation research efforts, including: (1) equipment limitations (i.e. suitable tag attachment methods, device size, finding funding for sufficient sample sizes), (2) access to and capture/handling of animals, (3) equipment and data recovery, and (4) creating the empirical link between science and policy that encourages support by managers. The first 3 of these challenges are magnified for immature life stages, which impose stronger size, weight, and recovery constraints on tags. Some lessons can be learned from terrestrial efforts, such as those involving but- terflies that carried extremely small, lightweight radar transponders to track their flight paths (Cant et al. 2005). Research involving birds who require small, lightweight tags can also provide insights into marine juvenile biologging techniques (Thorup et al. 2007, Egevang et al. 2010). Our knowledge of life histories can greatly benefit from combining biologging data with information from other sources, such as genetics, stable isotope analyses, modeling, and stranding and catch data (Wallace et al. 2006, Dutton et al. 2007, Godley et al. 2010, Taylor et al. 2011). Similarly, burgeoning efforts to develop high seas marine protected areas, define ecologically or biologically significant areas, and establish adaptivelymanaged marine reserve networks, will draw upon new tracking research that examines animal movements and behaviors across life history stages (Shillinger et al. 2008, 2010, Game et al. 2009, Dunn 2011).

Acknowledgements. The workshop was generously supported by funding from The Cinco Hermanos Foundation, Inter-Research, Collecte Localisation Satellites (CLS), CLSAmerica, The Leatherback Trust, Wildlife Computers, Desert Star Systems, and Telonics; 5 early career travel grants, funded by Inter-Research, were awarded to G. Blanco, S. Fossette, K. Mansfield, A. Stimpert, and R. Tyson. We are also grateful to the organizers of the Biologging IV Symposium for selecting our workshop to be part of this event.

\section{LITERATURE CITED}

Baker JD (2008) Variation in the relationship between offspring size and survival provides insight into causes of mortality in Hawaiian monk seals. Endang Species Res 5: 55-64

Barbour AB, Adams AJ (2012) Biologging to examine multiple life stages of an estuarine-dependent fish. Mar Ecol Prog Ser 457:241-250

> Block BA, Teo SLH, Walli A, Boustany A and others (2005) Electronic tagging and population structure of Atlantic bluefin tuna. Nature 434:1121-1127

> Block BA, Jonsen ID, Jorgensen SJ, Winship AJ and others (2011) Tracking apex marine predator movements in a dynamic ocean. Nature 475:86-90

> Bograd SJ, Block BA, Costa DP, Godley BJ (2010) Biologging technologies: new tools for conservation. Introduction. Endang Species Res 10:1-7

Bradshaw CJA, Barker RJ, Davis LS (2000) Modeling tag loss in New Zealand fur seal pups. J Agric Biol Environ Stat 5:475-485

Brander K (2010) Impacts of climate change on fisheries. J Mar Syst 79:389-402

Breed GA, Costa DP, Goebel ME, Robinson PW (2011) Electronic tracking tag programming is critical to data collection for behavioral time-series analysis. Ecosphere 2: art10

> Campagna C, Piola AR, Marin MR, Lewis MA, Zajaczkovski 
U, Fernández T (2007) Deep divers in shallow seas: southern elephant seals on the Patagonian shelf. DeepSea Res I 54:1792-1814

Cant ET, Smith AD, Reynolds DR, Osborne JL (2005) Tracking butterfly flight paths across the landscape with harmonic radar. Proc R Soc Lond B Biol Sci 272:785-790

Costa DP, Huckstadt LA, Crocker DE, McDonald BI, Goebel ME, Fedak MA (2010) Approaches to studying climatic change and its role on the habitat selection of Antarctic pinnipeds. Integr Comp Biol 50:1018-1030

Dunn DC (ed) (2011) Ecologically or biologically significant areas in the pelagic realm: examples and guidelinesworkshop report. IUCN, Gland

Dutton PH, Hitipeuw C, Zein M, Benson SR and others (2007) Status and genetic structure of nesting populations of leatherback turtles (Dermochelys coriacea) in the western Pacific. Chelonian Conserv Biol 6:47-53

Egevang C, Stenhouse IJ, Phillips RA, Petersen A, Fox JW, Silk JRD (2010) Tracking of Arctic terns Sterna paradisaea reveals longest animal migration. Proc Natl Acad Sci USA 107:2078-2081

> Evans PGH, Pierce GJ, Panigada S (2010) Climate change and marine mammals. J Mar Biol Assoc UK 90:1483-1487

Fedak M, Lovell P, McConnell B, Hunter C (2002) Overcoming the constraints of long range radio telemetry from animals: getting more useful data from smaller packages. Integr Comp Biol 42:3-10

> Fossette S, Putman NF, Lohmann KJ, Marsh R, Hays GC (2012) A biologist's guide to assessing ocean currents: a review. Mar Ecol Prog Ser 457:285-301

> Fuentes MMPB, Limpus CJ, Hamann M (2011) Vulnerability of sea turtle nesting grounds to climate change. Glob Change Biol 17:140-153

Game ET, Grantham HS, Hobday AJ, Pressey RL and others (2009) Pelagic protected areas: the missing dimension in ocean conservation. Trends Ecol Evol 24:360-369

- Gaspar P, Benson SR, Dutton PH, Réveillère A and others (2012) Oceanic dispersal of juvenile leatherback turtles: going beyond passive drift modeling. Mar Ecol Prog Ser 457:265-284

> Godley BJ, Blumenthal JM, Broderick AC, Coyne MS, Godfrey MH, Hawkes LA, Witt MJ (2008) Satellite tracking of sea turtles: Where have we been and where do we go next? Endang Species Res 4:3-22

Godley BJ, Barbosa C, Bruford M, Broderick AC and others (2010) Unravelling the migratory connectivity in marine turtles using multiple methods. J Appl Ecol 47:769-778

Hamann M, Grech A, Wolanski E, Lambrechts J (2011) Modelling the fate of marine turtle hatchlings. Ecol Model 222:1515-1521

> Hammerschlag N, Gallagher AJ, Lazarre DM (2011) A review of shark satellite tagging studies. J Exp Mar Biol Ecol 398:1-8

Hart KM, Fujisaki I (2010) Satellite tracking reveals habitat use by juvenile green sea turtles Chelonia mydas in the Everglades, Florida, USA. Endang Species Res 11: 221-232

> Hart KM, Sartain AR, Fujisaki I, Pratt HL Jr, Morley D, Feeley MW (2012) Home range, habitat use, and migrations of hawksbill turtles tracked from Dry Tortugas National Park, Florida, USA. Mar Ecol Prog Ser 457: 193-207

> Hays GC, Marsh R (1997) Estimating the age of juvenile loggerhead sea turtles in the North Atlantic. Can J Zool 75 : 40-46
Hays GC, Bradshaw CJA, James MC, Lovell P, Sims DW (2007) Why do Argos satellite tags deployed on marine animals stop transmitting? J Exp Mar Biol Ecol 349:52-60

Hays GC, Doyle TK, Houghton JDR, Lilley MKS, Metcalfe JD, Righton D (2008) Diving behaviour of jellyfish equipped with electronic tags. J Plankton Res 30: 325-331

Hays GC, Fossette S, Katselidis KA, Mariani P, Schofield G (2010) Ontogenetic development of migration: Lagrangian drift trajectories suggest a new paradigm for sea turtles. J R Soc Interface 7:1319-1327

Hazen EL, Maxwell SM, Bailey H, Bograd SJ and others (2012) Ontogeny in marine tagging and tracking science: technologies and data gaps. Mar Ecol Prog Ser 457: 221-240

Heithaus MR, Wirsing AJ, Dill LM, Heithaus LI (2007) Longterm movements of tiger sharks satellite-tagged in Shark Bay, Western Australia. Mar Biol 151:1455-1461

Hooker SK, Biuw M, McConnell BJ, Miller PJO, Sparling CE (2007) Bio-logging science: logging and relaying physical and biological data using animal-attached tags. Deep-Sea Res II 54:177-182

> Horning M, Hill RD (2005) Designing an archival satellite transmitter for life-long deployments on oceanic vertebrates: the life history transmitter. IEEE J Ocean Eng 30: $807-817$

Jones TT, Bostrom B, Carey M, Imlach B and others (2011) Determining transmitter drag and best-practice attachment procedures for sea turtle biotelemetry studies. Tech Memo NMFS, NOAA-TM-NMFS-SWFSC-480. NOAA, La Jolla, CA

Jonsen ID, Fleming JM, Myers RA (2005) Robust state-space modeling of animal movement data. Ecology 86: 2874-2880

Lindberg MS, Walker J (2007) Satellite telemetry in avian research and management: sample size considerations. J Wildl Manag 71:1002-1009

> Mansfield KL, Saba VS, Keinath JA, Musick JA (2009) Satellite tracking reveals a dichotomy in migration strategies among juvenile loggerhead turtles in the Northwest Atlantic. Mar Biol 156:2555-2570

Mansfield KL, Wyneken J, Rittschof D, Walsh M, Lim CW, Richards P (2012) Satellite tag attachment methods for tracking neonate sea turtles. Mar Ecol Prog Ser 457: 181-192

Mate B, Mesecar R, Lagerquist B (2007) The evolution of satellite-monitored radio tags for large whales: one laboratory's experience. Deep-Sea Res II 54:224-247

McClellan CM, Read AJ, Price BA, Cluse WM, Godfrey MH (2009) Using telemetry to mitigate the bycatch of longlived marine vertebrates. Ecol Appl 19:1660-1671

McConnell B, Fedak M, Hooker S, Patterson T (2010) Telemetry. In: Boyd IL, Bowen WD, Iverson SJ (eds) Marine mammal ecology and conservation: a handbook of techniques. Oxford University Press, Oxford, p 222-242

Melnychuk MC, Walters CJ, Christensen V, Bothwell ML, Welch DW (2012) Effects of solar ultraviolet radiation exposure on early ocean survival and fry-to-smolt growth of juvenile salmon. Mar Ecol Prog Ser 457: 251-264

> Okuyama J, Abe O, Nishizawa H, Kobayashi M, Yoseda K, Arai N (2009) Ontogeny of the dispersal migration of green turtle (Chelonia mydas) hatchlings. J Exp Mar Biol Ecol 379:43-50 
Pavlov VV, Rashed AM (2012) A non-invasive dolphin telemetry tag: computer design and numerical flow simulation. Mar Mamm Sci 28:E16-E27

Phillips RA, Xavier JC, Croxall JP (2003) Effects of satellite transmitters on albatrosses and petrels. Auk 120: 1082-1090

Ropert-Coudert Y, Beaulieu M, Hanuise N, Kato A (2009) Diving into the world of biologging. Endang Species Res 10:21-27

Rutz C, Hays GC (2009) New frontiers in biologging science. Biol Lett 5:289-292

Salmon M, Hamann M, Wyneken J, Schauble C (2009) Early swimming activity of hatchling flatback sea turtles Natator depressus: a test of the 'predation risk' hypothesis. Endang Species Res 9:41-47

Scott R, Marsh R, Hays GC (2011) A little movement orientated to the geomagnetic field makes a big difference in strong flows. Mar Biol 159:481-488

Seney EE, Higgins BM, Landry AM (2010) Satellite transmitter attachment techniques for small juvenile sea turtles. J Exp Mar Biol Ecol 384:61-67

Sherrill-Mix SA, James MC (2008) Evaluating potential tagging effects on leatherback sea turtles. Endang Species Res 4:187-193

Shillinger GL, Palacios DM, Bailey H, Bograd SJ and others (2008) Persistent leatherback turtle migrations present opportunities for conservation. PLoS Biol 6:e171 doi: 10.1371/journal.pbio.0060171

Shillinger GL, Swithenbank AM, Bograd SJ, Bailey H and others (2010) Identification of high-use internesting habitats for eastern Pacific leatherback turtles: role of the environment and implications for conservation. Endang Species Res 10:215-232

Shillinger GL, Di Lorenzo E, Luo H, Bograd SJ, Hazen EL, Bailey H, Spotila JR (2012) On the disperal of leatherback turtle hatchlings from Meso-American nesting beaches. Proc R Soc Lond B Biol Sci 279:2391-2395

Shimada T, Jones R, Limpus C, Hamann M (2012) Improving data retention and home range estimates by data-driven screening. Mar Ecol Prog Ser 457:171-180

Snoddy JE, Southwood Williard A (2010) Movements and post-release mortality of juvenile sea turtles released from gillnets in the lower Cape Fear River, North Carolina, USA. Endang Species Res 12:235-247

Szabo A, Duffus D (2008) Mother-offspring association in the humpback whale, Megaptera novaeangliae: following behaviour in an aquatic mammal. Anim Behav 75: 1085-1092

Taylor NG, McAllister MK, Lawson GL, Carruthers T, Block BA (2011) Atlantic bluefin tuna: a novel multistock spatial model for assessing population biomass. PLoS ONE 6:e27693

Teo SLH, Boustany A, Dewar H, Stokesbury MJW and others (2007) Annual migrations, diving behavior, and thermal biology of Atlantic bluefin tuna, Thunnus thynnus, on their Gulf of Mexico breeding grounds. Mar Biol 151:1-18

> Thorup K, Bisson IA, Bowlin MS, Holland RA, Wingfield JC, Ramenofsky M, Wikelski M (2007) Evidence for a navigational map stretching across the continental U.S. in a migratory songbird. Proc Natl Acad Sci USA 104: 18115-18119

Tyson RB, Friedlaender AS, Ware C, Stimpert AK, Nowacek DP (2012) Synchronous mother and calf foraging behaviour in humpback whales Megaptera novaeangliae: insights from multi-sensor suction cup tags. Mar Ecol Prog Ser 457:209-220

> Vandenabeele SP, Shepard EL, Grogan A, Wilson RP (2012) When three per cent may not be three per cent; deviceequipped seabirds experience variable flight constraints. Mar Biol 159:1-14

Wallace BP, Seminoff JA, Kilham SS, Spotila JR, Dutton PH (2006) Leatherback turtles as oceanographic indicators: stable isotope analyses reveal a trophic dichotomy between ocean basins. Mar Biol 149:953-960

> Wilson RP, McMahon CR (2006) Measuring devices on wild animals: What constitutes acceptable practice? Front Ecol Environ 4:147-154

Wilson RP, Shepard ELC, Liebsch N (2008) Prying into the intimate details of animal lives: use of a daily diary on animals. Endang Species Res 4:123-137

Wyneken J, Madrak SV, Salmon M, Foote J (2008) Migratory activity by hatchling loggerhead sea turtles (Caretta caretta L.): evidence for divergence between nesting groups. Mar Biol 156:171-178 